\title{
Should global political theory get real? An introduction
}

[This is a pre-proofs version of an introduction to a special edition of the Journal of International Political Theory. In order to cite, please use the published version, which is here: http://ipt.sagepub.com/content/early/2016/02/16/1755088216630997.abstract?rss=1]

Consider the following three 'growth areas' in political theory: (1) 'Global justice'; (2) 'just war'; and (3) the non-identical twins of realism/moralism and ideal/non-ideal theory. What instantly strikes one here? The fact that whilst the first two are incredibly ambitious research programmes, in terms of the gap between theoretical prescription and political reality, the third worries about that precise gap. And there is a lot of worrying about that gap. Right now, and regardless of the precise question posed and terminology invoked, it is hard to think of a more 'live' and varied conversation than the one that is currently going on about how ideal or pessimistic, how moralising or realistic, or how abstract or practical, political theory ought to be (Estlund, 2009; Farrelly, 2007; Geuss, 2008; Sen, 2011; Waldron, 2013; and Williams, 2005. For overarching discussion, see Rossi \& Sleat, 2014; and Valentini, 2012) ${ }^{1}$. Or at least, it is hard to think of a more excited conversation apart from those other two 'growth areas' just mentioned, which not only seem to have missed the 'are we realistic enough?' memo, but which also no doubt retain such excitement, at least in part, as a result of having done so.

With this in mind, it is time for us to think more about how realistic or otherwise we ought to be in the specific world of 'international' or 'global' political theory where, after all, theories of 'just war' and 'global justice' reside. Is this a domain in which the problems discussed within the moralism/realism and ideal/non-ideal theory debates apply to the same degree as 'domestic' political theory? Are they felt with greater force? Or do a different set of problems apply, either instead or in parallel? This is what we hope to explore in the following collection, by way of a set of responses to these and yet further questions, each of which brings together the methodological angst of the aforementioned 'how to do political theory' debates with the high moralising ambition of, say, theories of global justice.

\footnotetext{
${ }^{1}$ There are also three key collections on the topic: A special edition of Social Theory and Practice, $34: 3$ (2008), a special edition of the European Journal of Political Theory, 9:4 (2010); and (Floyd \& Stears, 2011). Note that by implying that these debates overlap, which they do, I am not saying that they are identical. Realists in particular are keen to stress the distinctiveness of their concerns - see (Rossi \& Sleat, 2014). My earliest thoughts on the 'new' realism can be found in (Floyd, 2010).
} 
These responses run as follows - and bear in mind that they are gathered in no particular order here, with the exception of David Miller's contribution, which takes its lead, in part, from the contributions that precede it. First, Mathias Risse explores several different conceptions of political philosophy with a view to figuring out just what the point is of writing books on, specifically, 'global justice'. Second, Aaron James affirms what many take to be the limited relevance of principled arguments, of the kind pursued in political theory, and including 'global' political theory, to the 'real-world' processes of public political argument and policy-formation. Third, Terry MacDonald explores the responsiveness of normative political principles to social facts, with specific reference to the justification and design of international institutions. Fourth, I explore the relevance to global political theory of a new idea regarding the justification of political principles - 'normative behaviourism' which works by looking for patterns, not in what I call our 'normative thoughts' (e.g. intuitions, considered judgements, hypothetical choices), but rather in our behaviour in response to particular political institutions.

Fifth, Matt Sleat explores, with much of the debate about contemporary realism in mind, the idea of global justice as a specifically 'political' value. Sixth, Chris Bertram distinguishes between principle-based, model-based and realist approaches to justice, again with reference to institutions, and wonders whether it is possible to have a non-institutional account of justice at all. Seventh, Shmulik Nili makes the case that we ought to be more focused on realworld moral failures in our theorising, and also more informed by contemporary socialscience, whilst acknowledging the limits of the latter. And finally, eighth, David Miller distinguishes between different kinds of political realism, before arguing that the domestic domain differs significantly from the international one when it comes to principles and their justification, specifically in terms of the problems of agency and legitimacy that confront anyone wanting to do political theory at that level, whether we call such theory 'realist' or not.

So, to repeat: we currently have a situation in which some of us worry about how realistic political theory ought to be, whilst others, particularly at the international or global level, pursue (what many consider to be) some of the most unrealistic political theory seen for some time (though of course, one could say as much for some strands of e.g. 'republican' or 'luckegalitarian' theory). Is there a tension here? Or are these complementary activities, as suggested, say, by the ideal/non-ideal division of labour? Again, we hope to shed light on 
such things in this collection. And so, as a result, regardless of whether one sees the recent worrying about idealism and realism as a sign of political ambition (we want to be more relevant!), philosophical curiosity (we haven't thought much about this before), or even a crisis of confidence (is there any point to what we're doing?), there is surely something for all appetites here. Naturally though, the (realistic!) hope in all this is not for finality, in the sense of settling such matters, but rather only for an open-ended contribution to our knowledge of them, the surest sign of which is always as follows: in response to the tentative answers provided from here on in, new questions are triggered further down the line.

\section{References}

Estlund D (2009) Democratic authority: a philosophical framework. Princeton, NJ: Princeton University Press.

Estlund D (2011) Human nature and the limits (if any) of political philosophy. Philosophy \& Public Affairs, 39(3), 207-237.

Farrelly C (2007) Justice in ideal theory: A refutation. Political Studies, 55(4), 844-864.

Floyd J (2010) Should political philosophy be more realistic? Res Publica, (16(3), 337-347.

Floyd J \& Stears M. (eds) (2011) Political philosophy versus history? contextualism and real politics in contemporary political thought. Cambridge: Cambridge University Press.

Geuss R (2008) Philosophy and real politics. Princeton, NJ: Princeton University Press.

Rossi E \& Sleat M (2014) Realism in Normative Political Theory. Philosophy Compass, 9(10), 689-701.

Sen A (2011) The Idea of Justice. Cambridge: MA: Harvard University Press.

Valentini L (2012) Ideal vs. Non-ideal Theory: A Conceptual Map. Philosophy Compass, $7(9), 654-664$. 
Waldron J (2013) Political Political Theory: An Inaugural Lecture. Journal of Political Philosophy, 21(1), 1-23.

Williams BAO (2005) In the beginning was the deed: realism and moralism in political argument. Princeton, NJ: Princeton University Press. 